Article

\title{
Gamification for Classroom Management: An Implementation Using ClassDojo
}

\author{
Azucena Barahona Mora
}

Department of English Studies, Faculty of Philology, Complutense University of Madrid, 28040 Madrid, Spain; azucenab@ucm.es

Received: 30 September 2020; Accepted: 4 November 2020; Published: 11 November 2020

check for updates

\begin{abstract}
In the present educational context, active methodologies and new technologies are aspects that should be included when teaching and learning a subject area. For the education to be successful, classroom management must be considered, since problems may arise and handicap this process. In order to promote learning and reduce negative behaviors and increase positive ones, intervention on students of 1st year of ESO (compulsory secondary education) was implemented. The intervention used gamification as the educational approach and ClassDojo as the online tool to track behavior to determine the effectiveness of both elements to achieve the goal. Taking advantage of the game design principles and mechanics in the learning environment to create motivation and interest, in addition to the information and communication technologies (ICT) represented by ClassDojo, the experimental study showed the benefit of this method and app regarding the improvement of desired behaviors as well as the decrease of the disruptive ones. The implementation engaged the students and activated their behavioral development in order to display a better performance.
\end{abstract}

Keywords: gamification; ClassDojo; classroom management; behavioral problems; secondary education

\section{Introduction}

This paper presents a case study of using a digital tool to manage classroom behavior in a secondary school. The importance of this study is because classroom management is a crucial aspect of the teaching and learning experience and it may enhance or disrupt its flow.

Undesirable behavior is an issue that must be prevented at schools. Class rules, routines and procedures must be established for the students to know how to behave properly in both the academic and social contexts. The behavioral skills they develop are abilities that will transcend their school life. Teenagers are trained for adulthood and are prepared to live in society by managing their actions, feelings and thoughts. During this process, students have to learn how to self-regulate applying flexible attention, working memory and inhibitory control [1]. This means that children must ignore the distractions that surround them when doing their tasks, remember and follow the rules and control impulsivity.

Throughout secondary education, students are often troublesome and have challenging attitudes that must be solved to avoid unpleasant situations for a better education. In this context, teachers not only give curricular lessons, they are also managers that control their classes from a behavioral point of view. Teachers, using their professional training and experience, and students, developing their social, emotional and learning habits and skills, are responsible for an appropriate environment that enables participation, engagement, respect, collaboration, discipline and responsibility, among others. The good practices of teachers regarding conflicts must result in prevention, intervention, resolution, negotiation, mediation and the ability to transform disruptive situations into positive ones. Students are usually aware of their behavior, but sometimes they are not, so it is necessary that they learn to realize. Negative behaviors are, for example, standing up, speaking or borrowing things without permission, 
being disrespectful with the teacher and classmates, throwing things to their classmates such as chalk or balls of paper, not following directions or not doing their homework.

Undesired behavior interrupts the classroom dynamics. Under these circumstances, the teacher has to spend their own teaching time correcting these attitudes that are caused by different reasons $[1,2]$ :

- School failure refers to a low learning achievement that stops the student from meeting the minimum objectives of a certain school level. This situation may lead to boredom and demotivation.

- Social reasons, such as maladjustment, which is reflected in lying, theft, school absenteeism, bullying or vandalism, marginality due to sex, culture and origin, problems in their family environment owing to their economic situation or physical and verbal violence, and lack of social skills.

- School factors, like the relationship with the classmates and preferences regarding teachers and subjects.

- Psychological or learning problems, such as low self-esteem, attention deficit hyperactivity disorder and the youngsters' developmental stage.

It also has consequences for the teachers. They may be stressed, apathetic and demotivated, which can result in burnout.

Considering that a classroom is a small community that must have rules and foundations in order to learn in a safe training atmosphere, gamification is an appropriate method since games and their elements are characterized by their socializing role.

Gamification is a term that was initially used in the field of the digital media industry, which was coined by a computer game developer named Nick Pelling at the beginning of the 21st century to create interfaces for electronic devices. Since then, different authors and researchers have formulated a variety of definitions for this concept, including "the use of game-thinking and game mechanics to engage users and solve problems" [3] (p. XIV); "the use of game design elements in non-game contexts" [4] (p. 2); "using game-based mechanics, aesthetics and game-thinking to engage people, motivate action, promote learning and solve problems," [5] (p. 10); "the use of game elements and game-design techniques in non-game contexts" [6] (p. 26); "the use of games and game-like approaches to solve problems and create better experiences" [7] (p. 4).

It has become very popular in other fields, such as e-commerce [8,9], business [10,11], software engineering and development $[12,13]$ and healthcare $[14,15]$.

As it was stated in the definition of gamification, this method implies the use of certain elements that come from games, which are to be considered to program a gamified experience and are pieces that build the blocks that integrate it. A series of common design elements in games which can be extrapolated to gamified systems are determined by [4]:

- Interface design patterns: badges, levels, leaderboards.

- Game design patterns or game mechanics: time constraint, limited resources, turns.

- Design principles or heuristics: guidelines for solving a problem or evaluating a solution.

- Game models: fantasy, curiosity.

- Game design methods: playtesting, playcentric, value-conscious.

Three levels are defined by [3,6], but with some differences. The following ones are suggested by [3]:

- Mechanics represent the components that make the game function and guide the actions of the players. For example, points, levels, leaderboards, badges, onboarding, dashboards, challenges and quests, customization.

- Dynamics are related to the interaction of the players with the mechanics and their response to them, based on the recognition of achievements, gaining status, leading others, creating order, among others.

- Aesthetics refers to the feelings and emotions the player has during the action. 
The elements that constitute gamification are also dynamics and mechanics [6], but the authors also introduce the components. The first ones are the most abstract, providing realism to the activity and encouraging participants to play. They are the emotions, constraints, narrative, progression and relationships. The second ones make reference to the processes to engage and motivate the players: challenges, cooperation, chance, competition, rewards, transactions, turns, feedback, resource acquisition and win states. The components are the manifestation of the mechanics and are connected to the dynamics in the sense that they enable the ability to achieve the programmed objectives. They are classified into avatars, badges, achievements, teams, points, quests, boss fights, collections, combat, content unlocking, gifting, leaderboards, levels, social graphs and virtual goods.

Regarding education, gamification is considered an active methodology [16-19]. This approach refers to the techniques, methods and strategies that are used by the teachers for the students to participate in their learning, which is centered on the process of doing the activities. The students are the protagonists of the training, and cooperate, create and get engaged. This constructivist methodology involves cooperative learning (they need to interact and exchange ideas with their partners when working in groups to succeed in the task), autonomy (they are responsible for their learning) and the development of the competence related to learning to learn (discovering and collecting information and selecting and using it, critical thinking and making decisions). This ability enables them to plan, manage and fix objectives to determine the possible results; thus, they self-assess their learning and can improve their skills for the subsequent activities. Teachers, on their side, become mediators that facilitate learning, manage the class, provide materials and give the students feedback about their performance.

The integration of ICT into the educational system has developed innovations in the processes of teaching and learning, including the virtual learning environments, which are web-based platforms that provide tools for educational purposes; at the same time, they become a place of social communication [20]. Related to behavioral aspects at school, they help complement aspects such as the syllabus, cooperative conflict resolution or parent training [21]. Many teachers have included the educational platforms as a tool to implement the elements of their gamified lesson plans. In this regard, gamification "involves adding a layer of "game" in e-campaigns, e-learning, e-business, e-commerce, and e-health, for example, allowing users to perform tasks, education or to encourage different attitudes or changes in human behavior" [22] (p. 2). ClassDojo is a good example. It is an online classroom-management app that helps teachers record and supervise students' behavior. Researchers, such as [23-26], state that this app improves behaviors, it is versatile, it allows the personalization of objectives according to the students, it is motivating and teachers, parents and pupils are connected to track progress.

Moreover, in an educational context, gamification, which has a ludic nature, facilitates the internalization of the concepts in a motivating way which generates a positive experience for the student. It promotes interest in the activities, developing their engagement with their learning and encouraging their spirit of improvement in order to get good results in the tasks while, at the same time, they are absorbing knowledge in an attractive and entertaining way [27]. It persuades them in order to transform an ordinary activity into an appealing challenge that is worth continuing. Their results when performing are measured in levels, points and badges, which develop competitivity but also collaboration. This competitivity motivates the students externally; that is to say, they find an advantage or a reward when learning that makes them do their best for their own sake. That is the deep level of motivation [7]. The challenges stimulate them to succeed in order to be rewarded, so that they become satisfied with their actions, get engaged and motivated [28-30]. Additionally, the positive emotions that students feel when they are rewarded and the negative ones when they are penalized have the purpose of reinforcing their learning process. According to [31], the view they have of their assessment when they do a gamified activity is different compared with other methods because they do not lose marks for their performance [32]; they get them for doing the task properly. 
During the creation of gamified activities, teachers have to take the abilities and the previous knowledge of their students into consideration, due to the fact that the level of the challenges could be either high or low and the objectives may not be achieved. These situations may cause stress, frustration and fear of failure, and boredom and loss of interest, so it is important that they perceive the activities as a flow in which they are focused and engaged [33]. Furthermore, they need to be designed considering the pupils' interests, expectations and differences, which affect their learning. Because of that, learners are classified into groups of players in order to adapt the educational experiences to their necessities. The most important method of categorization of players in a game is the one by Bartle [34]:

- Killers: they are interested in acting on other players to show their superiority and to be admired.

- Achievers: they find it very important to act on the world and control and master the game.

- Socializers: they like to interact with other players. The game is just a setting to find out about others.

- Explorers: they are concerned about interacting with the world. That leads them to get deep knowledge about the game.

Later, this classification was adapted for gamification by Marczewski, as shown in Table 1.

Table 1. Marczewski gamification user types [35] (pp. 231-232).

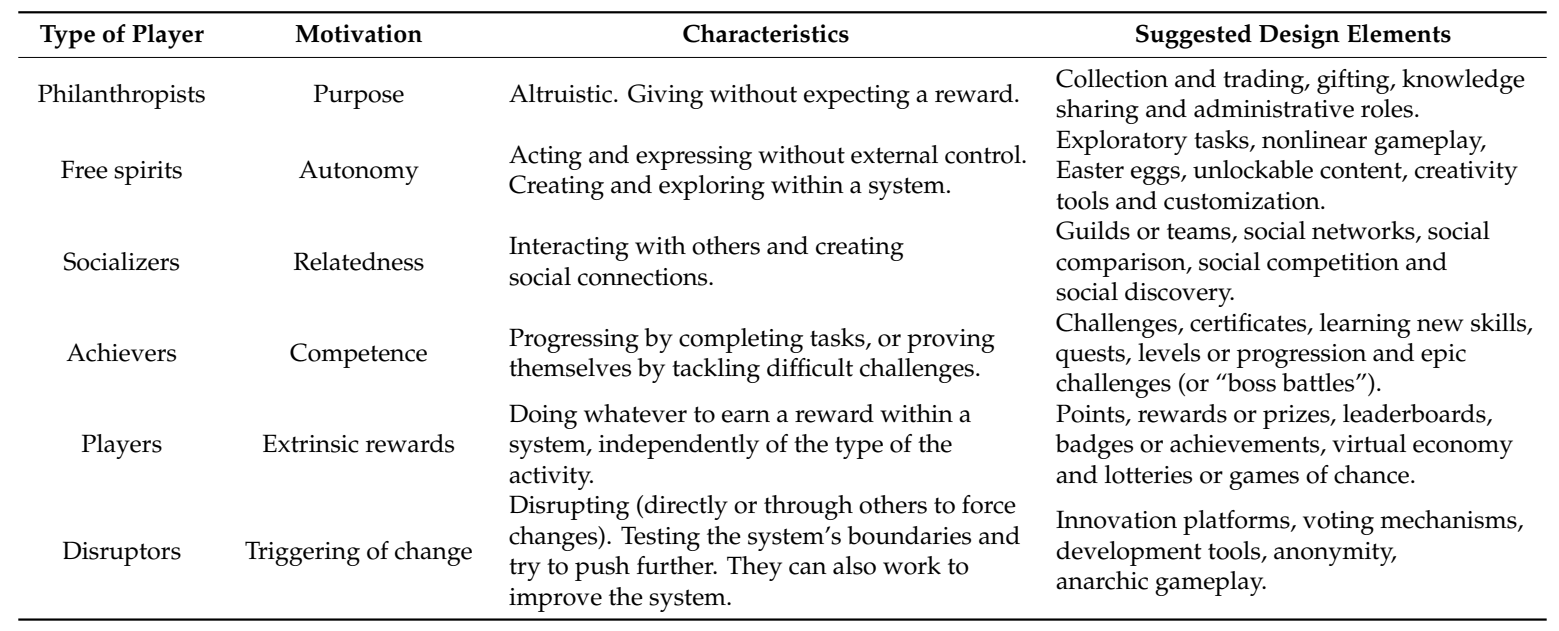

In relation to the methodological basis that is used in gamification [6], designed a framework that is applicable in education, as Figure 1 shows.

\begin{tabular}{|c|c|c|}
\hline Objectives & $\begin{array}{l}\text { - Goals to be achieved with the activity implemented and their } \\
\text { benefits. }\end{array}$ \\
\hline - Attitudes and competences to be encouraged and developed \\
on the students
\end{tabular}

Figure 1. Werbach and Hunter game design framework applied to gamification in an educational context. 
This theoretical approach supports the exploratory case study that is presented in the next section, which has as the main aim to prevent the negative behaviors of a group of students of secondary education and increase and maintain the desired ones. To achieve it, a gamified implementation was carried out using ClassDojo. At the end of the intervention, they improved their behavior significantly; therefore, the positive influence of gamification and ICT on their attitudes in the classroom was confirmed.

\section{Materials and Methods}

This study was carried out through the framework of the gamification method and it followed the experimental design based on a quantitative perspective. The implementation of the research and the analyses of the results were conducted with the online application ClassDojo.

\subsection{Participants}

The participants of this implementation were 21 students of 1st year of ESO (compulsory secondary education), ranging from 12 to 13 years old, of a school center in Madrid.

The preceding academic year, they attended 6th grade of primary education in different schools, so they had to start a new stage. They were new pupils at the high school and most of them had not met before.

Particularly, one student was diagnosed with attention deficit hyperactivity disorder, four had general low learning performance, two repeated the grade, one was bullied previously and another one was marginalized by their classmates.

After being together for a month, the tutor observed some negative behaviors that had to be improved and/or corrected. They were caused due to previous habits, unfamiliarity with the rules of the educational center and attitudinal problems.

\subsection{Instruments}

The app ClassDojo was used as a data collector. In it, the points the students earned and their kind, and the percentage of negative and positive behaviors, were shown. It is free, it is necessary to create an account and it can be seen on a cell phone, tablet or computer. Teachers give feedback to the students about their performance and, also, inform their families. Since the collaboration of the parents is essential in the educational guidance [36,37], contributing, for example, emotional support, complementing the school rules and detecting risky situations that can affect their children's behavior, this app creates a community connecting teachers and parents in order to work closely. The educators share videos, photos and different activities the pupils do in the classroom and both teachers and parents can send comments on the students' work. At the same time, parents can notify teachers of any information. All this interaction provides mutual support and helps the pupils to have a consistent and significant educational experience to promote change and growth. Positive reinforcement related to skills and behavior is the goal in order to increase and maintain good attitudes. With this online system, students earn points for desired behaviors and lose them for undesired ones. The teachers have to establish the discipline plan they want to work with, and score so the pupils clearly see what is expected from them. The students have to choose an avatar and can participate in the creation of the classroom rules and their icons. The whole class has its own story, but also each schoolchild has one. Moreover, the app includes a chronometer, music, noises, an agenda and an attendance record. Data can be continuously collected, feedback is given at any time (e.g., daily, weekly or monthly) and when they have earned the highest rating, they get a certificate. In addition, as they get groups of points, they could receive rewards, such as stickers or passes. Results are compiled into charts and representations. 


\subsection{Procedure}

The study was carried out for four weeks by the tutor of the class, who was also their Spanish, English and History teacher, so he spent fourteen class hours a week with them out of a total of twenty-five.

It followed different phases. First, the tutor identified the negative behaviors and, with the collaboration of the students, created the list of the skills to be developed. Each one was represented by an icon.

Table 2 shows the negative behaviors that had to be improved and the positive ones that had to be maintained and achieved.

Table 2. Negative and positive behaviors.

\begin{tabular}{llll}
\hline \multicolumn{2}{c}{ Negative Behaviors } & & \multicolumn{1}{c}{ Positive Behaviors } \\
\hline A. Speaking or standing up without permission & A. & Raising their hand to speak and ask a question \\
B. Talking during classwork & B. Working quietly during classwork \\
C. Talking while the teacher is explaining/correcting & C. Being quiet while the teacher is explaining/correcting \\
D. Throwing paper balls to the classmates or making noises & D. Focus on work without getting distracted \\
E. Being disrespectful with the teacher & E. Being respectful with the teacher \\
F. Being disrespectful with their classmates & F. Being respectful with their classmates \\
G. Not doing their homework & G. Doing their homework \\
H. Using their cell phone & H. Following directions \\
I. Sitting down inappropriately & I. Collaborative work \\
\hline
\end{tabular}

Second, the teacher sent an email to the parents explaining the activity, its goals and the use of the app ClassDojo. Then, it was implemented. The students had their own account and chose their avatar and the icons for each skill, as Figure 2 shows. They were rewarded 1 point for their positive behaviors (Figure 3a) and were deducted 2 points for their negative ones (Figure $3 b$ ).

The points were collected daily, so they could check their progress every day and their total every Friday. The teacher reflected with the students on their performance during the compulsory weekly class hour that is stated by the official curriculum [38]. Additionally, their parents had access to the data and received feedback. When earning 50 positive points or more in one positive skill, they were rewarded with badges with the image of the icon related to that behavior, which were redeemed for 10 extra ones of the same category that were added to the score of the following week.

The final score was gathered after four weeks. Lastly, the results were analyzed.

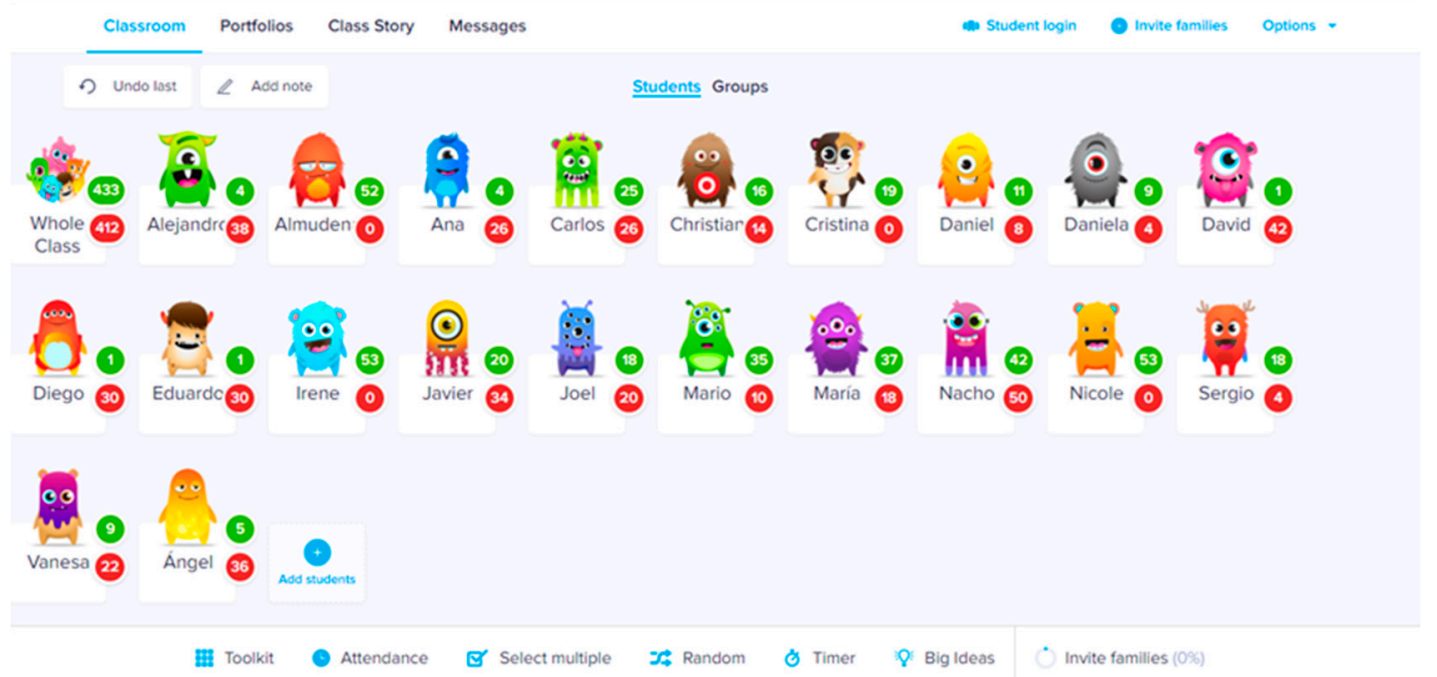

Figure 2. Example of students' avatars and score. 


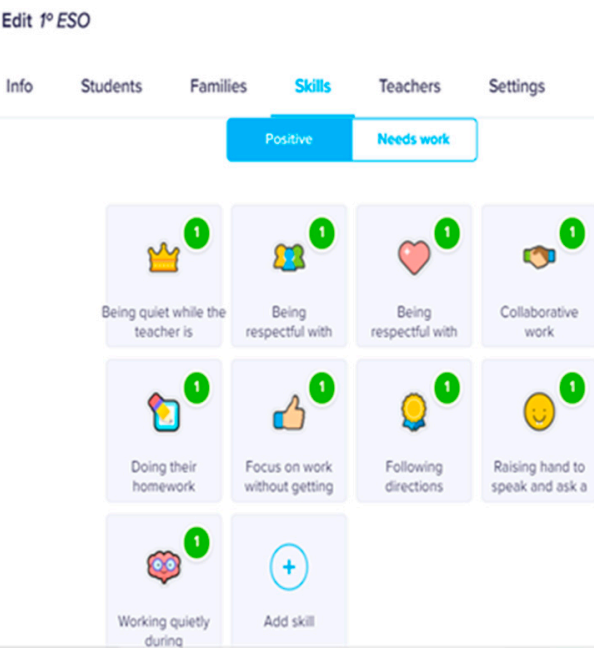

(a)

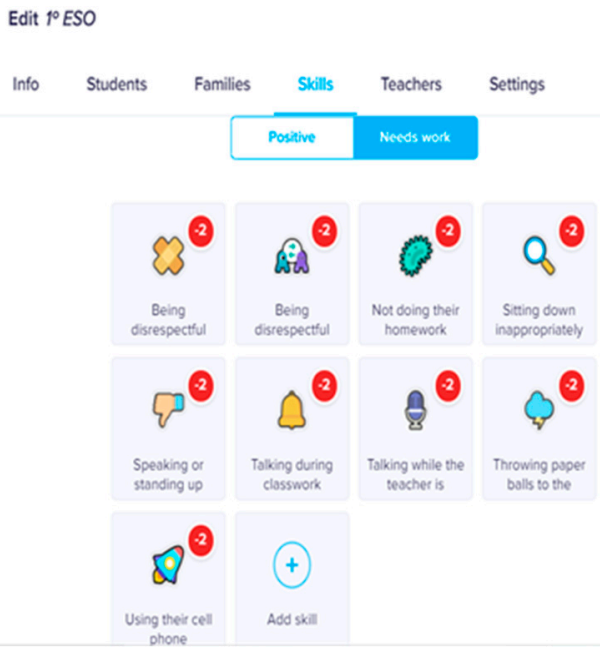

(b)

Figure 3. (a) Positive and (b) negative skills, points and icons.

\section{Results}

The first week of implementation, the students earned a total of 476 positive points and lost 576 for negative behaviors.

Talking during classwork was the most common negative behavior and the least common one was being disrespectful with the teacher. Regarding the positive behaviors, being quiet while the teacher was explaining and correcting obtained the highest percentage. Being disrespectful with their classmates got the lowest. Figure 4 collects the points earned in each behavior.

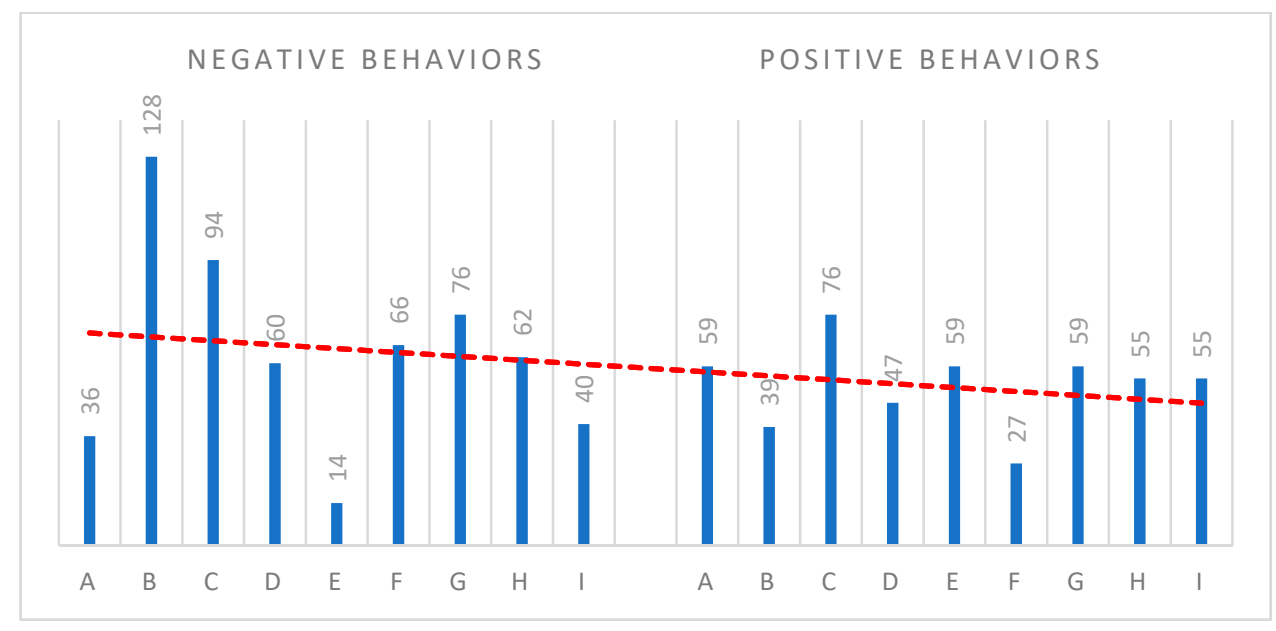

Figure 4. Negative and positive points after the first week.

Table 3 shows the percentage of positive and negative behaviors according to the total points earned in each of them this week.

Specifically, only 3 students met all the goals $100 \%$, and 13 obtained less than $50 \%$. Table 4 shows the results.

At the end of the second week, the number of positive behaviors recorded was slightly lower (447), but there was an improvement regarding the score of the negative points (412), as shown in Figure 5 . This downward trend meant $52 \%$ of desired behaviors were achieved. 
Table 3. Percentage of behaviors after the first week.

\begin{tabular}{cccc}
\hline \multicolumn{3}{c}{ Behaviors } \\
\hline \multicolumn{2}{c}{ Negative } & \multicolumn{2}{c}{ Positive } \\
\hline A & $6.25 \%$ & A & $12.39 \%$ \\
B & $22.22 \%$ & B & $8.19 \%$ \\
C & $16.31 \%$ & C & $15.96 \%$ \\
D & $10.41 \%$ & D & $9.87 \%$ \\
E & $2.43 \%$ & E & $12.39 \%$ \\
F & $11.45 \%$ & F & $5.67 \%$ \\
G & $13.19 \%$ & G & $12.39 \%$ \\
H & $10.76 \%$ & H & 11.55 \\
I & $6.94 \%$ & I & $11.55 \%$ \\
\hline
\end{tabular}

Table 4. Percentage of positive behaviors according to each student during the first week.

\begin{tabular}{cccccc}
\hline \multicolumn{5}{c}{ Positive Behaviors } \\
\hline \multicolumn{5}{c}{ Students } \\
\hline 1 & $100 \%$ & 10 & $84 \%$ & 19 & $2 \%$ \\
2 & $100 \%$ & 11 & $39 \%$ & 20 & $2 \%$ \\
3 & $100 \%$ & 12 & $46 \%$ & 21 & $2 \%$ \\
4 & $46 \%$ & 13 & $58 \%$ & & \\
5 & $69 \%$ & 14 & $31 \%$ & & \\
6 & $76 \%$ & 15 & $20 \%$ & & \\
7 & $85 \%$ & 16 & $9 \%$ & & \\
8 & $40 \%$ & 17 & $6 \%$ & & \\
9 & $37 \%$ & 18 & $10 \%$ & & \\
\hline
\end{tabular}

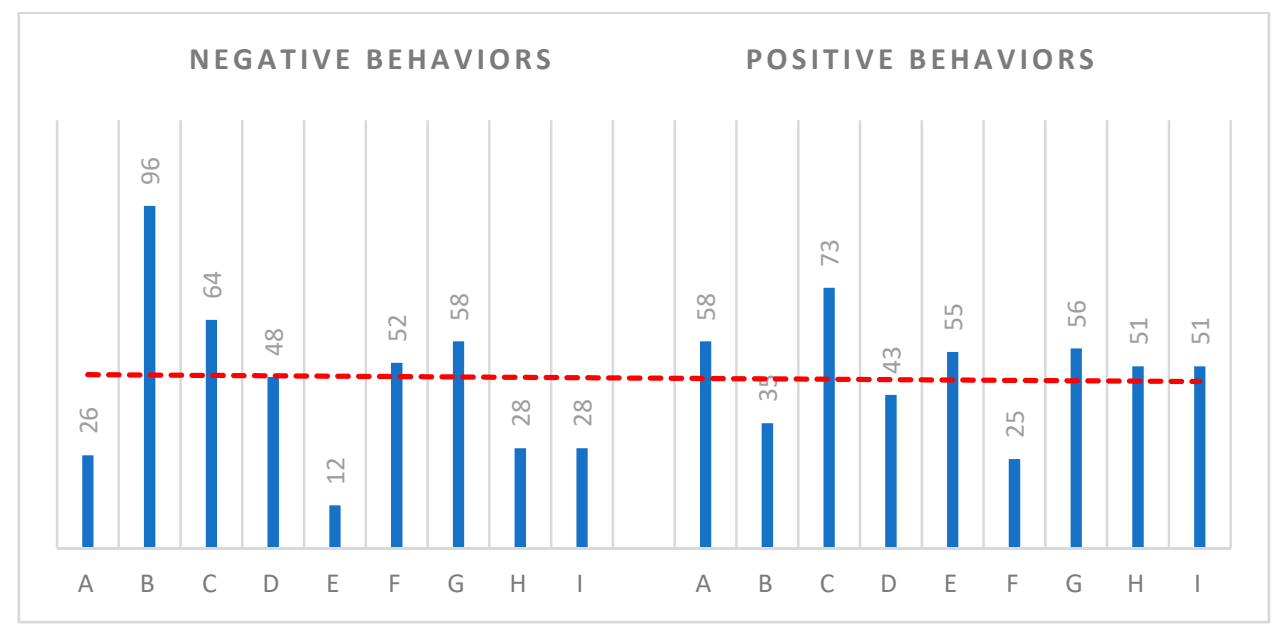

Figure 5. Negative and positive points after the second week.

That week the students earned a lower number of negative points in all the behaviors, as Table 5 shows. The most substantial difference lies in the behaviors related to using their cell phones, throwing paper balls and talking while the teacher was explaining or correcting.

During this period, all the students improved or maintained their performance (see Table 6). In particular, 4 students achieved the highest score of positive behaviors, 100\%, 11 increased their results, 5 remained unchanged and 1 lowered the result.

At the end of the third week, there was a total of 721 positive behaviors recorded, which meant a remarkable increase if compared with the first and second weeks, but the most significant result was the one that occurred in the negative behaviors, which dropped to 196. 
Table 5. Percentage of behaviors after the second week.

\begin{tabular}{cccc}
\hline \multicolumn{4}{c}{ Behaviors } \\
\hline \multicolumn{2}{c}{ Negative } & \multicolumn{2}{c}{ Positive } \\
\hline A & $6.31 \%$ & A & $12.97 \%$ \\
B & $23.3 \%$ & B & $7.82 \%$ \\
C & $15.53 \%$ & $\mathrm{C}$ & $16.33 \%$ \\
D & $11.65 \%$ & D & $9.61 \%$ \\
E & $2.91 \%$ & E & $12.3 \%$ \\
F & $12.62 \%$ & $\mathrm{~F}$ & $5.59 \%$ \\
G & $14.07 \%$ & G & $12.52 \%$ \\
H & $6.79 \%$ & H & $11.4 \%$ \\
I & $6.79 \%$ & I & $11.4 \%$ \\
\hline
\end{tabular}

Table 6. Percentage of positive behaviors according to each student after the second week.

\begin{tabular}{cccccc}
\hline \multicolumn{5}{c}{ Positive Behaviors } \\
\hline \multicolumn{5}{c}{ Students } \\
\hline 1 & $100 \%$ & 10 & $100 \%$ & 19 & $2 \%$ \\
2 & $100 \%$ & 11 & $47 \%$ & 20 & $3 \%$ \\
3 & $100 \%$ & 12 & $53 \%$ & 21 & $2 \%$ \\
4 & $46 \%$ & 13 & $58 \%$ & & \\
5 & $67 \%$ & 14 & $69 \%$ & & \\
6 & $78 \%$ & 15 & $29 \%$ & & \\
7 & $89 \%$ & 16 & $12 \%$ & & \\
8 & $49 \%$ & 17 & $10 \%$ & & \\
9 & $37 \%$ & 18 & $13 \%$ & & \\
\hline
\end{tabular}

Most of the behaviors dropped substantially, as shown in Figure 6, such as talking during classwork and while the teacher was explaining and correcting, being disrespectful with their classmates, throwing paper balls to the classmates or making noises and speaking and standing without permission. Being disrespectful to the teacher obtained half of the points with regard to the previous week and using their cell phone and sitting down inappropriately kept similar values. On the other hand, the highest positive behaviors were doing their homework and working quietly during classwork, which implied an important change compared to the past weeks. Following directions and being respectful with the classmates also improved notably. Table 7 shows the results.

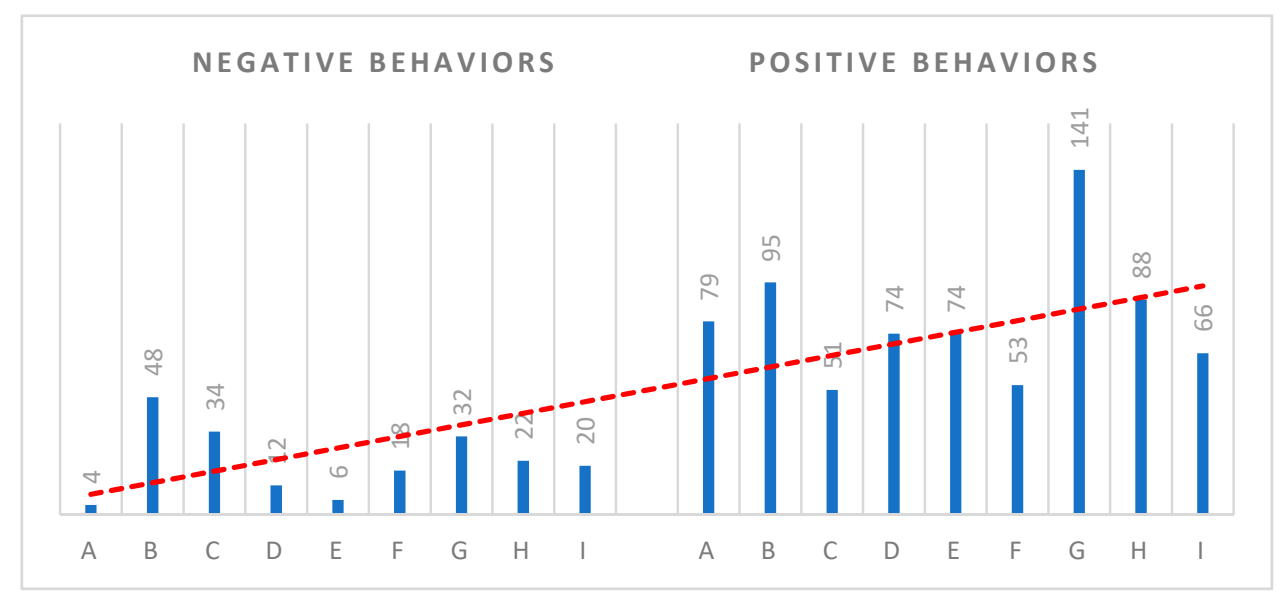

Figure 6. Negative and positive points after the third week. 
Table 7. Percentage of positive behaviors according to each student after the third week.

\begin{tabular}{cccc}
\hline \multicolumn{3}{c}{ Behaviors } \\
\hline \multicolumn{2}{c}{ Negative } & \multicolumn{2}{c}{ Positive } \\
\hline A & $2.04 \%$ & A & $10.95 \%$ \\
B & $24.48 \%$ & B & $13.17 \%$ \\
C & $17.34 \%$ & C & $7.07 \%$ \\
D & $6.12 \%$ & D & $10.26 \%$ \\
E & $3.06 \%$ & E & $10.26 \%$ \\
F & $9.18 \%$ & F & $7.35 \%$ \\
G & $16.32 \%$ & G & $19.55 \%$ \\
H & $11.22 \%$ & H & $12.2 \%$ \\
I & $10.20 \%$ & I & $9.15 \%$ \\
\hline
\end{tabular}

As Table 8 shows, the number of students who obtained $100 \%$ of positive behaviors did not change, but there was a sharp increase in the number of the ones who improved their behavior: 8 students reached more than $80 \%$ and 6 got between $68 \%$ and $79 \%$.

Table 8. Percentage of positive behaviors according to each student after the third week.

\begin{tabular}{cccccc}
\hline \multicolumn{5}{c}{ Positive Behaviors } \\
\hline \multicolumn{5}{c}{ Students } \\
\hline 1 & $100 \%$ & 10 & $100 \%$ & 19 & $5 \%$ \\
2 & $100 \%$ & 11 & $85 \%$ & 20 & $79 \%$ \\
3 & $100 \%$ & 12 & $87 \%$ & 21 & $77 \%$ \\
4 & $72 \%$ & 13 & $92 \%$ & & \\
5 & $96 \%$ & 14 & $79 \%$ & & \\
6 & $93 \%$ & 15 & $84 \%$ & & \\
7 & $90 \%$ & 16 & $49 \%$ & & \\
8 & $93 \%$ & 17 & $7 \%$ & & \\
9 & $68 \%$ & 18 & $79 \%$ & \\
\hline
\end{tabular}

During the last week of intervention, the students earned 996 points and lost 132, which meant $87 \%$ percent of positive behaviors, an optimal value with respect to the previous weeks (see Figure 7).

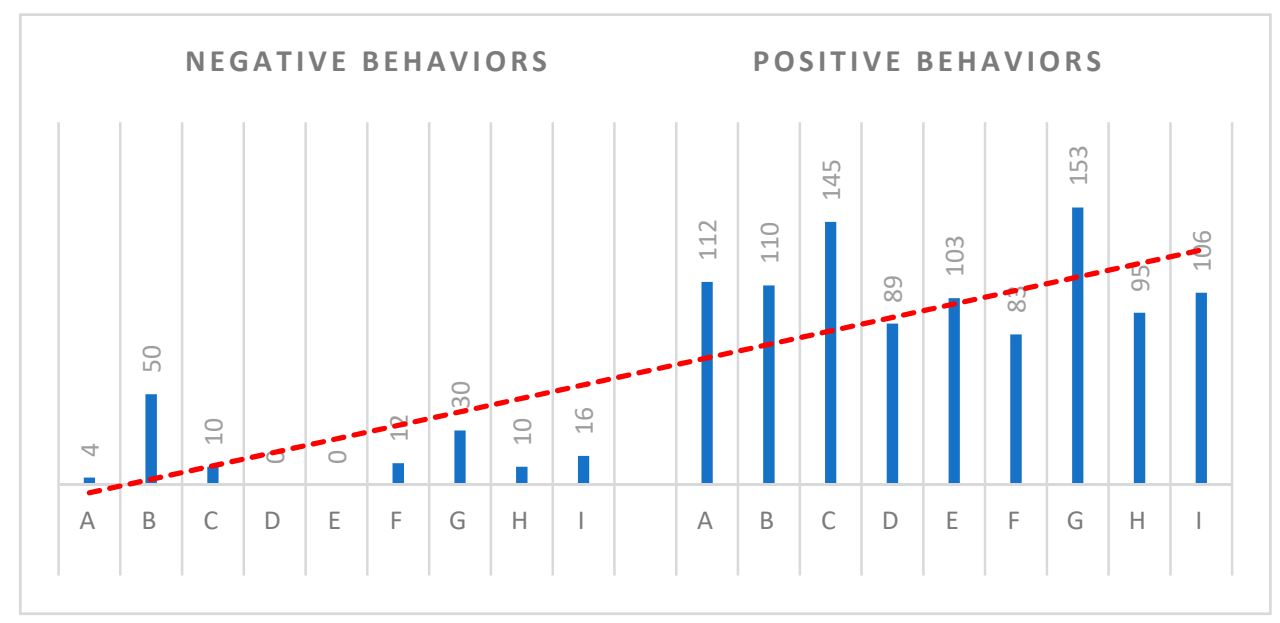

Figure 7. Negative and positive points after the fourth week.

There was a sharp decrease regarding the negative behaviors, while even some of them did not occur, as shown in Table 9. Talking while the teacher was explaining or correcting dropped, a low result considering previous weeks, as well as using their cell phones. About the positive ones, there was an 
improvement in all of the behaviors. Doing homework, being quiet while the teacher was explaining and correcting, raising their hand to speak and ask a question, being respectful with the teacher and collaborative work obtained the highest score.

Table 9. Percentage of positive behaviors according to each student after the fourth week.

\begin{tabular}{cccc}
\hline \multicolumn{3}{c}{ Behaviors } \\
\hline \multicolumn{2}{c}{ Negative } & \multicolumn{2}{c}{ Positive } \\
\hline A & $3.03 \%$ & A & $11.24 \%$ \\
B & $37.87 \%$ & B & $11.04 \%$ \\
C & $7.57 \%$ & C & $14.55 \%$ \\
D & $0 \%$ & D & $8.93 \%$ \\
E & $0 \%$ & E & $10.34 \%$ \\
F & $9.09 \%$ & F & $8.33 \%$ \\
G & $22.72 \%$ & G & $15.36 \%$ \\
H & $7.57 \%$ & H & $9.53 \%$ \\
I & $12.12 \%$ & I & $10.64 \%$ \\
\hline
\end{tabular}

Concerning the students particularly (Table 10), they achieved peak performance compared to the past weeks.

Table 10. Percentage of positive behaviors earned according to each student after the fourth week.

\begin{tabular}{cccccc}
\hline \multicolumn{5}{c}{ Positive Behaviors } \\
\hline \multicolumn{5}{c}{ Students } \\
\hline 1 & $100 \%$ & 10 & $100 \%$ & 19 & $78 \%$ \\
2 & $100 \%$ & 11 & $88 \%$ & 20 & $80 \%$ \\
3 & $100 \%$ & 12 & $90 \%$ & 21 & $85 \%$ \\
4 & $76 \%$ & 13 & $93 \%$ & & \\
5 & $97 \%$ & 14 & $83 \%$ & & \\
6 & $93 \%$ & 15 & $84 \%$ & & \\
7 & $91 \%$ & 16 & $73 \%$ & & \\
8 & $93 \%$ & 17 & $19 \%$ & & \\
9 & $83 \%$ & 18 & $87 \%$ & & \\
\hline
\end{tabular}

Figure 8 shows the group evolution during the whole intervention. The number of points of the negative behaviors declined as the gamified experience was implemented (Figure 8a), while the positive ones increased (Figure 8b).

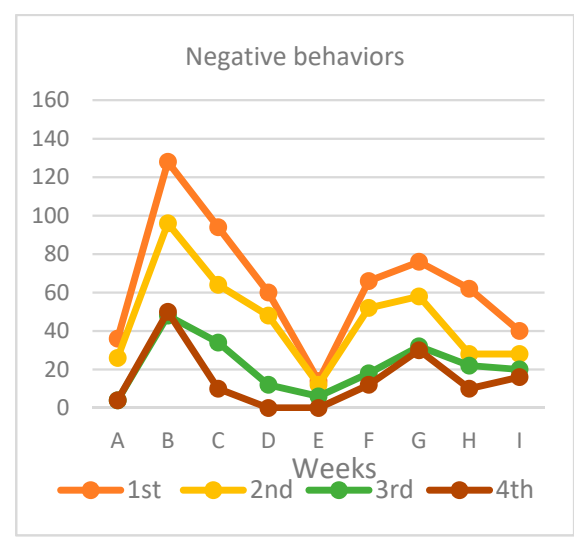

(a)

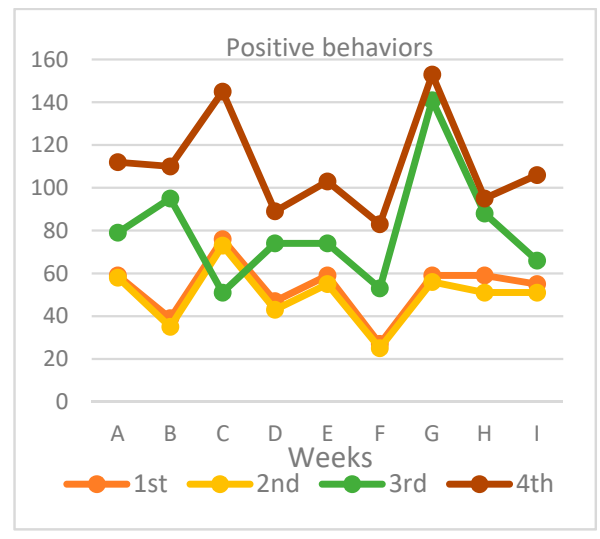

(b)

Figure 8. Group weekly evolution according to (a) negative and (b) positive behaviors. 
On the other hand, as Figure 9 shows, the students' positive behaviors improved week after week, especially in pupils 18,19, 20, 21 and 22. Numbers 1, 2, 3 and 10 reached the best results; in contrast, student 17 had a poor performance.

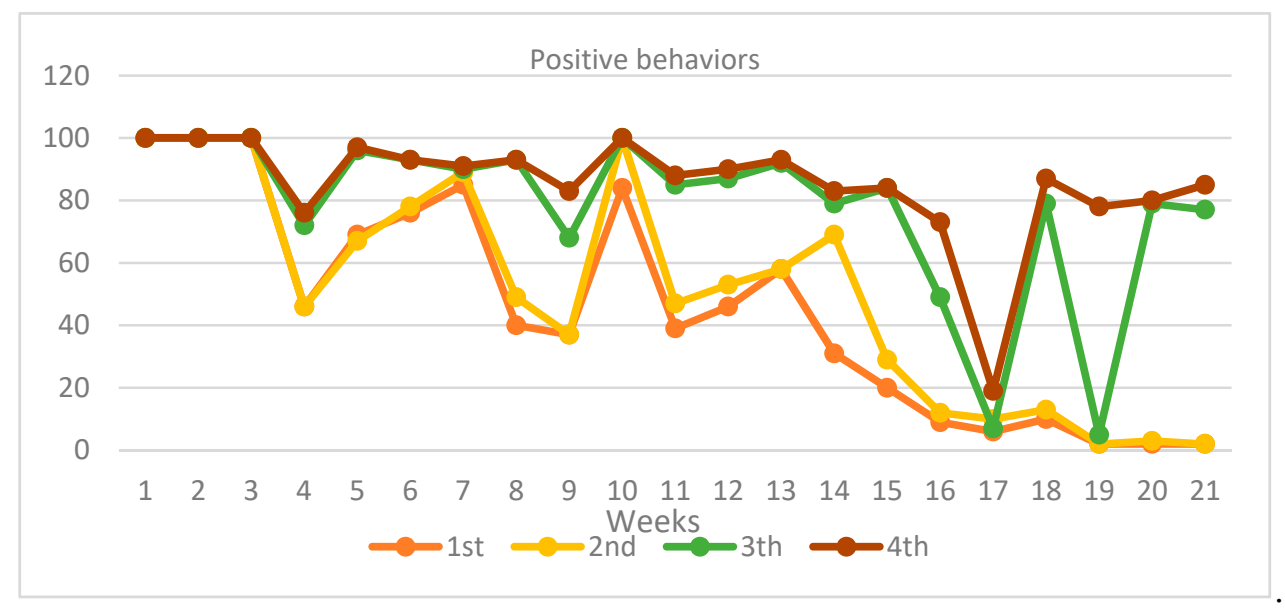

Figure 9. Students' weekly evolution.

\section{Discussion}

Talking during classwork and while the teacher was explaining and correcting were the behaviors that had the highest score at the end of the weeks. The students got distracted very easily when they did their activities alone or in groups or when they must listen to the teacher, for example, talking about any topic with their classmates or laughing. They had to be controlled closely for them to focus on the task. Most of the students, to a greater or lesser extent, did it during the experience.

Likewise, not doing their homework started as an undesired behavior that improved as the weeks went on; however, it did not reach very low values. This situation was due to the fact that the students who had general low learning performance and repeated the grade, numbers 15, 16, 17, 18, 19, 20 and 21, hardly ever did their homework during the intervention. Additionally, they were disruptors, according to Marczewski's classification. Fortunately, some of them, numbers, 15, 18, 20 and 21, changed their attitudes radically during the third and fourth weeks.

On the other hand, being disrespectful with their classmates was a negative behavior that earned a great amount of points, especially owing to two students, 4 and 11, who were very rude with the pupil who was bullied in previous years, number 10. These two students had a very high academic performance, but they were bad-mannered. This circumstance changed dramatically in student 11 throughout the intervention and improved slightly in number 4. Pupil 10 was not influenced by these two students and obtained excellent performance. Similarly, student 18, who was marginalized by some classmates, earned negative points during the first and second weeks, caused, mainly, by lack of motivation. This person made progress thanks to the digital tool, which helped him to show their skills to the rest of the class. He started to be a socializer, according to Marczewski.

Speaking or standing up without permission, using their cell phones and sitting down inappropriately were practically eradicated at the end of the intervention. Regarding the last behavior, as well as throwing paper balls to the classmates and making noises, it was student 16 in particular who did it most of the time, in addition to students 9 and 14, who did it occasionally. They used the chair to sway, they lay on the table and turned around. Pupil 16 was diagnosed with attention deficit hyperactivity disorder. Despite being prescribed medication, this teenager still had some trouble focusing.

Being disrespectful with the teacher dropped straight away after the second week. They immediately learnt that this behavior was unacceptable. This, together with throwing paper balls, did not earn any points during the last week. 
With reference to positive behaviors, there was a sharp increase in their performance, especially after the second week. At that time, the students thoroughly thought about their results and realized how negative their behavior was. When they rechecked their points and the teacher's feedback after the first week and they received again negative values at the end of the second one, they were really aware of the toxic educational environment they were in. They decided it was time to change because their attitude had a negative effect on their learning process. They corrected behaviors of other classmates, they strived to better themselves to earn positive points and badges, and competitiveness, motivation, collaboration and engagement emerged more strongly than in previous weeks. This willingness to be rewarded and the positive feelings that it caused reinforced their behavior, as outlined by [28-30].

Additionally, it must be added that parents collaborated with the teacher for their children's success. They received a report every week with personalized comments which complemented the information issued by the app. As [21] stated, it helped the understanding and communication between the home and the classroom. This way, they strengthened the work carried out by the teacher.

In respect to students, specifically numbers 1,2 and 3 had excellent performance throughout the implementation. According to Marczewski, they were achievers. Nevertheless, the student number 17 particularly did not meet the goals because distraction, disruption and lack of work were behavioral problems associated with this person that could not be improved.

According to the results, doing their homework, being quiet while the teacher was explaining and correcting, raising their hand to speak and ask a question, working quietly during classwork, being respectful to the teacher and collaborative work rose in frequency, reaching more than 100 points in the final week. This led to less interruptions and to a greater use of the teaching time.

Moreover, they focused to a larger extent on work without getting distracted and followed directions, which implied they recognized the need to consider the teacher's corrections and act under the rules.

Furthermore, by developing the skills of working collaboratively and being more respectful, they improved the relationships with their classmates. In this sense, it can be stated that redirecting students' behavior and reinforcing the positive ones had an impact not only on them as individuals, but also as a group.

As demonstrated in previous studies [23-26], this educational experience is consistent with the idea that the inclusion of gamification as an active methodology and ClassDojo as a digital tool brings benefits for the improvement of desired behaviors and the decrease of the undesired ones. Students self-regulated their behaviors by being tracked and correcting their attitudes with the aim of raising their learning process. Therefore, the use of these two elements represented high efficiency in the field of correcting behavioral problems in the classroom, a critical fact that should be considered for further research.

Funding: This research received no external funding.

Conflicts of Interest: The author declares no conflict of interest.

\section{References}

1. McClelland, M.M.; Cameron, C.E. Self-regulation and academic achievement in elementary school children. In Thriving in Childhood and Adolescence: The Role of Self-Regulation Processes; Lerner, R.M., Lerner, J.V., Bowers, E.P., Lewin-Bizan, S., Gestsdottir, S., Brown, U.J., Eds.; John Wiley \& Sons: Hoboken, NJ, USA, 2011; pp. 29-44.

2. Ureta, C.V.D.M. Intervención Educativa y Orientadora Para la Inclusión Social de Menores en Riesgo: Factores Escolares y Socioculturales; UNED: Madrid, Spain, 2008.

3. Zichermann, G.; Cunningham, C. Gamification by Design: Implementing Game Mechanics in Web and Mobile Apps.; O’Reilly Media: Sebastopol, CA, USA, 2011. 
4. Deterding, S.; Dixon, D.; Khaled, R.; Nacke, L. From Game Design Elements to Gamefulness: Defining "Gamification", Proceedings of the 15th International Academic MindTrek Conference: Envisioning Future Media Environments, Tampere, Finland, 28-30 September 2011; Lugmayr, A., Franssila, H., Safran, C., Hammouda, I., Eds.; ACM: New York, NY, USA, 2011; pp. 9-15.

5. Kapp, K.M. The Gamification of Learning and Instruction: Game-Based Methods and Strategies for Training and Education; Wiley: San Francisco, CA, USA, 2012.

6. Werbach, K.; Hunter, D. For the Win: How Game Thinking Can Revolutionize Your Business; Wharton Digital Press: Philadelphia, PA, USA, 2012.

7. Marczewski, A. Gamification: A Simple Introduction; Lulu: Raleigh, NC, USA, 2013.

8. Insley, V.; Nunan, D. Gamification and the online retail experience. Int. J. Retail Distrib. Manag. 2014, 42, 340-351. [CrossRef]

9. Noorbehbahani, F.; Salehi, F.; Jafar, Z.R. A systematic mapping study on gamification applied to e-marketing. J. Res. Interact. Mark. 2019, 13, 392-410. [CrossRef]

10. Owen, P. How Gamification Can Help Your Business Engage in Sustainability; Routledge: New York, NY, USA, 2017.

11. Gudiksen, S.; Inlove, J. Gamification for Business: Why Innovators and Changemakers Use Games to Break Down Silos, Drive Engagement and Build Trust; Kogan Publishers: New York, NY, USA, 2018.

12. Machuca-Villegas, L.; Gasca-Hurtado, G.P. Estrategias de gamificación con fines de mejora de procesos software en la gestión de proyectos. Rev. Ibérica Sist. Tecnol. Inf. 2019, 17, 142-155.

13. Platonova, V.; Bērziša, S. Gamification in software development projects. Inf. Technol. Manag. Sci. 2017, 20, 58-63. [CrossRef]

14. Sardi, L.; Idri, A.; Fernández-Alemán, J.L. A systematic review of gamification in e-Health. J. Biomed. Inform. 2017, 71, 31-48. [CrossRef] [PubMed]

15. Garett, R.; Young, S.D. Health care gamification: A study of game mechanics and elements. Technol. Knowl. Learn. 2019, 24, 341-353. [CrossRef]

16. Gómez, T.I.M.; Bañuls, M.R. Análisis de metodologías activas con ABP, Transmedia y gamificación para implementar las competencias en ciencias sociales y en literatura. In Investigación en Docencia Universitaria: Diseñando el Futuro a Partir de la Innovación Educativa; Roig-Vila, R., Ed.; Octaedro: Barcelona, Spain, 2017; pp. 245-254.

17. Forndran, F.; Zacharias, C.R. Gamified experimental physics classes: A promising active learning methodology for higher education. Eur. J. Phys. 2019, 40, 045702. [CrossRef]

18. Muntaner, J.J.; Pinya, C.; Mut, B. El impacto de las metodologías activas en los resultados académicos. Profr. Rev. Currículum Form. Profr. 2020, 24, 96-114. [CrossRef]

19. Segura-Robles, A.; Fuentes-Cabrera, A.; Parra-González, M.E.; López-Belmonte, J. Effects on Personal Factors Through Flipped Learning and Gamification as Combined Methodologies in Secondary Education. Front. Psychol. 2020, 11, 1103. [CrossRef] [PubMed]

20. Barahona Mora, A. El desarrollo de la expresión escrita en inglés a través del entorno virtual de aprendizaje. In Contribuciones de la Tecnología Digital en el Desarrollo Educativo y Social; Coord, R., Ed.; Adaya Press: Eindhoven, NL, USA, 2020; pp. 1-11.

21. Pantoja Vallejo, A. Acción tutorial y nuevas tecnologías. In La Acción Tutorial: Su Concepto y su Práctica; Álvarez, G.M., Castilla, E.C., Eds.; Ministerio de Educación y Ciencia: Madrid, Spain, 2006; pp. $219-262$.

22. Rodrigues, L.F.; Oliveira, A.; Rodrigues, H. Main gamification concepts: A systematic mapping study. Heliyon 2019, 5, e01993. [CrossRef] [PubMed]

23. Robacker, C.M.; Rivera, C.J.; Warren, S.H. A token economy made easy through ClassDojo. Interv. Sch. Clin. 2016, 52, 39-43. [CrossRef]

24. Williamson, B. Decoding ClassDojo: Psycho-policy, social-emotional learning and persuasive educational technologies. Learn. Media Technol. 2017, 42, 440-453. [CrossRef]

25. Rivera, C.J. Using ClassDojo as a Mechanism to Engage and Foster Collaboration in University Classrooms. Coll. Teach. 2019, 67, 154-159. [CrossRef]

26. Manolev, J.; Sullivan, A.; Slee, R. The datafication of discipline: ClassDojo, surveillance and a performative classroom culture. Learn. Media Technol. 2019, 44, 36-51. [CrossRef]

27. Hew, K.; Huang, B.; Chu, W.S.; Chiu, D.K. Engaging Asian students through game mechanics: Findings from two experiment studies. Comput. Educ. 2016, 92, 221-236. [CrossRef] 
28. Kocadere, S.A.; Çağlar, Ş. The design and implementation of a gamified assessment. J. E-Learn. Knowl. Soc. 2015, 11, 86-99.

29. Da Rocha Seixas, L.; Gomes, A.S.; De Melo Filho, I.J. Effectiveness of gamification in the engagement of students. Comput. Hum. Behav. 2016, 58, 48-63. [CrossRef]

30. Alsawaier, R.S. The Effect of Gamification on Motivation and Engagement. Int. J. Inf. Learn. Technol. 2018, 35, 56-79. [CrossRef]

31. Shpakova, A.; Dörfler, V.; MacBryde, J. Gamification and innovation: A mutually beneficial union. In Proceedings of the 30th Annual Conference of the British Academy of Management, Newcastle upon Tyne, UK, 6-8 October 2016.

32. Sheldon, L. Practical Game Design: A Toolkit for Educators, Researchers, and Corporations; Delmar Cengage Learning: New York, NY, USA, 2012.

33. Csikszentmihalyi, M. Flow: The Psychology of Optimal Experience; Harper Collins: New York, NY, USA, 2008.

34. Bartle, R. Hearts, clubs, diamonds, spades: Players who suit MUDs. J. MUD Res. 1996, 1, 19-58.

35. Tondello, G.F.; Wehbe, R.R.; Diamond, L.; Busch, M.; Marczewski, A.; Nacke, L.E. The gamification user types hexad scale. In Proceedings of the 2016 Annual Symposium on Computer-Human Interaction in Play, Austin, TX, USA, 16-19 October 2016.

36. Pantoja Vallejo, A. La Acción Tutorial en la Escuela; Síntesis: Madrid, Spain, 2013.

37. González, M.A.; Alzina, R.B. Orientación Educativa: Modelos, Áreas, Estrategias y Recursos; Wolters Kluwe: Madrid, Spain, 2018.

38. ORDEN 2398/2016, de 22 de Julio, de la Consejería de Educación, Juventud y Deporte de la Comunidad de Madrid, Por la Que se Regulan Determinados Aspectos de Organización, Funcionamiento y Evaluación en la Educación Secundaria Obligatoria. Available online: https://www.bocm.es/boletin/CM_Orden_BOCM/ 2016/08/09/BOCM-20160809-1.PDF (accessed on 1 June 2020).

Publisher's Note: MDPI stays neutral with regard to jurisdictional claims in published maps and institutional affiliations.

(C) 2020 by the author. Licensee MDPI, Basel, Switzerland. This article is an open access article distributed under the terms and conditions of the Creative Commons Attribution (CC BY) license (http://creativecommons.org/licenses/by/4.0/). 